\title{
The Role of the Courts in Advancing Water Security in South Africa
}

\author{
B Qumbu*
}

\section{P.E.R}

Pioneer in peer-reviewed, open access online law publications

Author

\section{Bronwen Qumbu}

\section{Affiliation}

North-West University

South Africa

Email

Bronwen.Qumbu@nwu.ac.za

Date Submission

12 October 2020

Date Revised

29 August 2021

Date Accepted

2 September 2021

Date published

29 September 2021

Series Editor Prof AA du Plessis

Section Editor Dr IL Owosuyi

How to cite this article

Qumbu B "The Role of the Courts in Advancing Water Security in South Africa" PER / PELJ 2021(24) - DOI http://dx.doi.org/10.17159/17273781/2021/v24i0a9004

\section{Copyright}

DOI

http://dx.doi.org/10.17159/17273781/2021/v24i0a9004

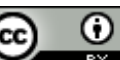

\begin{abstract}
This article explores the role which courts could play in promoting water security in South Africa. As the country is one of the driest on the continent, its water security issues remain at the forefront of the service delivery conundrum. Therefore, issues of water security often need to be litigated to arrive at a favourable and just outcome. This is where the focus of this article lies. Based on a critical analysis of the legal framework governing water security and relevant case law, the article argues that courts could promote water security by discharging certain duties. Firstly, the courts must uphold the applicable law by weighing the rights and interests that relate to water and must then make reasonable, just and equitable findings. Secondly, the courts must solve water-related disputes between parties by interpreting and applying the applicable laws and policies. It is submitted that by executing these two functions, the courts contribute to a deeper understanding of the water security discourse. Finally, it is argued that through the execution of their traditional judicial functions, courts contribute to the making of law that directly affects water security.
\end{abstract}

\section{Keywords}

Water security; right of access to water; protection of water resources; local government; role of courts; judiciary. 


\section{Introduction}

South Africa is regarded as the $30^{\text {th }}$ most water-scarce country in the world. ${ }^{1}$ Pollution, climate change, a rising demand for water, lack of infrastructure as well as the effects of past discriminatory laws further exacerbate this dire situation. ${ }^{2}$ Despite the constitutional right of access to sufficient water, ${ }^{3}$ many people still live in deplorable conditions without access to clean drinking water. After the first democratic elections in 1994 it was estimated that approximately 14 million people in South Africa did not have access to clean water for domestic use and over 20 million people did not have sufficient water for sanitation. ${ }^{4}$ In 2019 it was estimated that $44,9 \%$ of South African households had access to piped water in their dwellings. ${ }^{5} \mathrm{~A}$ further $28,5 \%$ accessed water on their property while $14,7 \%$ relied on communal taps or surrounding neighbours' taps. ${ }^{6}$ Although households' access to water had improved, $1,6 \%$ of households still had to fetch water from rivers, streams, stagnant water pools, dams, wells and springs in 2019. ${ }^{7}$

Access to water is only one component of water security. Water also needs to be affordable for access to be realised and of a quality suitable for human consumption. However, of the South African households that have access to piped water in their dwellings, only $44,6 \%$ reported paying for these water services. ${ }^{8}$ This could be attributed to many factors such as the poor debt collection processes of municipalities, dysfunctional water supply services or social factors including poverty and unemployment. In an already poverty-stricken country, the affordability of water seems to be put under the spotlight in terms of litigation. ${ }^{9}$

* Bronwen Qumbu. LLB LLM. Lecturer, Faculty of Law, North-West University (Potchefstroom Campus), South Africa. Email: Bronwen.Qumbu@nwu.ac.za. ORCID 0000-0002-3816-4903. This article is based on the author's LLM dissertation titled: "The Role of the Courts in Promoting Water Security in South Africa" (NorthWest University, 2019). Thank you to Prof Oliver Fuo and Dr Felix Dube for their valuable insights and critique.

1 Department of Water Affairs 2013 https://www.dwa.gov.za/documents/Other/ Strategic\%20Plan/NWRS2-Final-email-version.pdf 8.

Gabru 2005 PELJ 2; Honkonen 2017 PELJ 2.

See s 27 of the Constitution of the Republic of South Africa, 1996.

Stein 2005 Tex L Rev 2169.

Stats SA 2018 http://www.statssa.gov.za/publications/P0318/P03182019.pdf.

Stats SA 2018 http://www.statssa.gov.za/publications/P0318/P03182019.pdf.

Stats SA 2018 http://www.statssa.gov.za/publications/P0318/P03182019.pdf.

Stats SA 2018 http://www.statssa.gov.za/publications/P0318/P03182019.pdf.

See the discussion of the Mazibuko cases in part five of this article. 
The role which courts play in the realisation of the right to water in South Africa is particularly important. In a country plagued by post-Apartheid inequities, where the poorest of the poor still endure the most of poor service delivery, the court is a necessary tool to bring justice to and pursue equity for those affected parties. Issues surrounding water security are often overlooked due to an already broken system and therefore it is important to make use of the legislative mechanisms afforded to the public to ensure that the fundamental right to water is realised and upheld, and that those bodies mandated with this task are held accountable.

The Constitution of the Republic of South Africa, 1996 (hereafter the Constitution), guarantees everyone the right to access to water. ${ }^{10}$ This right must be progressively realised through legislative and other measures. ${ }^{11}$ This provision suggests positive action from the State, and in terms of the Constitution, the local authorities are responsible for the water supply. ${ }^{12}$ It is therefore not strange that in many cases where the legal issue involves water security municipalities are cited as defending parties. The importance of these cases cannot be emphasised enough. Courts can play a significant role in ensuring that the right to water is achieved through various orders and declarations by carrying out their constitutional mandate amongst other duties. ${ }^{13}$ In certain cases a supervisory interdict has the necessary force to compel a local authority to fulfil its mandate. Where legislation provides the necessary mechanisms, parties may also be held criminally liable for their actions. These cases as well as those where neither option is utilised and where the court has unfortunately failed to advance the notion of water security will be discussed in this article.

This article comprises six parts in which both international and domestic literature and domestic legislation on the subject matter are explored. Three different judgments are analysed, originating from an unreported lower court judgment right through to high court and constitutional court judgments. First, a brief exposition of some of the theoretical perspectives of water security is provided to understand the different components. Secondly, the legal framework as it relates to water security is analysed. An overview of the courts' constitutional mandate and functions is discussed in part four. In part five an analysis of cases where the court has been confronted with

Section 27(1)(b) of the Constitution.

Section 27(1)(c) of the Constitution.

Section 156 of the Constitution.

These duties will be discussed and expanded on in part 4 . 
issues of water security follows, and finally, recommendations and concluding remarks are made.

\section{Theoretical perspectives on water security}

Water security has been given many definitions over time, most of which tend to divide the term into different components. The United Nations Water Security Initiative identifies the components as the capacity of a population to secure sustainable access to sufficient quality and quantities of water, the affordability of such water, and the protection of water resources. ${ }^{14}$ Sadoff and Muller ${ }^{15}$ define water security as "the reliable availability of an acceptable quantity and quality of water for health, livelihoods and production, coupled with an acceptable level of water-related risks". The Global Water Partnership states that at any level, water security means that every person has access to sufficient and affordable safe water to lead a clean, healthy and productive life while ensuring that the natural environment is protected and enhanced. ${ }^{16}$ From these definitions alone, three core components emerge, namely affordability, sustainable access and the protection of resources. It is contended that for water security to be achieved, all three components need to be present and fulfilled. For example, if physical access to water is guaranteed but such access is not affordable, it cannot be said that the access provided is in any way sustainable. Similarly, if water resources are not protected there can be no quality supply to distribute to consumers.

Sustainable access to water in this context entails that decision-makers consider social, economic and environmental factors and the needs of the present and future generations. ${ }^{17}$ The protection of water resources is an integral part of the notion of water security. Cook and Baker ${ }^{18}$ argue that the anthropocentric element contained in the right to access results in a failure to address the inclusion of the ecosystem as an integral part of water security. The inclusion of the ecosystem places an obligation ${ }^{19}$ on the

UN-Water Water Security 1.

Sadoff and Muller Water Management 11.

Global Water Partnership 2000 http://www.gwp.org/globalassets/global/toolbox/ references/towards-water-security.-a-framework-for-action.-mobilising-political-willto-act-gwp-2000.pdf.

17 Du Plessis and Nel "An introduction" 3-9.

18 Cook and Bakker 2012 Global Environmental Change 97.

19 Fisher "Jurisprudential Model for Sustainable Water Resources Governance" 141143. 
authorities tasked with ensuring access to take positive steps to protect water resources for the end goal of ensuring water security.

Water security can be said to have been attained when all the main components in the various definitions reviewed above are present in a given context. Although water security is not synonymous with the right to water, it should be considered as a factor in determining whether the right has been realised. This is because it has a noticeable impact on the right to life and the right to dignity, ${ }^{20}$ and as stated by Mirumachi, ${ }^{21}$ water issues are closely associated with other developmental problems such as food production, land development and climate change. ${ }^{22}$ In contrast, water insecurity exists where one or more of the core components of water security is not present. This suggests that there is no sustainable access to water resources or that although there may be access to water resources, these resources are not protected. This could therefore lead to a systematic decline in access, which would not be sustainable to start with. Versteeg ${ }^{23}$ describes the term "water scarcity" to identify those situations in which basic human needs might potentially not be fulfilled due to a lack of water.

When sustainable, affordable access and the protection of water resources are achieved, and these components are present simultaneously, water security can be achieved. These three components are interrelated, as shown above. In reviewing these different perspectives on water security, and despite the semantics, it is the view of this author that the core components of water security can be described as sustainable access to affordable water ${ }^{24}$ and the protection of water resources. The existence of these components lies at the centre of the judicial conundrum - how can the court promote water security, more specifically, how can the court ascertain the presence of the core components. It is therefore important to

20 Boisson de Chazournes, Leb and Tignino are of the view that the protection of access to water is related to the protection of health. See Boisson de Chazournes, Leb and Tignino "Introduction" in this regard. General Comment No 15 is explicit in its assertion that delivery of the human right to water is "indispensable for leading a life in human dignity", and also that this right "is a prerequisite for the realization of other human rights". See UNCESCR General Comment No. 15: The Right to Water (Arts 11 and 12 of the International Covenant on Economic, Social and Cultural Rights) UN Doc E/C.12/2002/11 (2003) para 1.

$21 \quad$ Mirumachi Transboundary Water Security 2.

22 Climate change has a significant impact on water security and is one of the leading causes of water insecurity, particularly in developing countries such as many African countries. The Intergovernmental Panel on Climate Change (IPCC) projects that climate change will reduce the renewable surface and groundwater resources of the world, especially in rural areas. See the IPCC Climate Change 201413.

23 Versteeg 2006 Tilburg Foreign L Rev 370.

24 Grey and Sadoff 2007 Water Policy 547-548. 
analyse how these components are addressed in the legislative regime governing water security in South Africa. Considering these two components, regulatory instruments should make provision for them before it can be said that water security is adequately addressed.

\section{The legal framework addressing water security in South Africa}

The South African water law regime pre-1994 can best be described as colonial and oppressive. The law was based on racially discriminatory systems which also influenced the distribution of water. ${ }^{25}$ Due to the laws regulating the ownership of land, water rights were not equitably distributed. ${ }^{26}$ The water sector legislation was overhauled drastically and replaced upon the advent of the new constitutional dispensation, with statutes that reflect the vision and purport expressed in the preamble to the 1996 Constitution:

[To] heal the divisions of the past and establish a society based on democratic values, social justice and fundamental human rights; Lay the foundations for a democratic and open society in which government is based on the will of the people and every citizen is equally protected by law; Improve the quality of life of all citizens and free the potential of each person.

The National Water Act 36 of 1998 (hereafter the NWA) promulgated in 1998 replaced about one hundred other Acts $^{27}$ dealing with water use, allocation and conservation in South Africa. ${ }^{28}$ The NWA, which should be read with the Water Services Act 108 of 1997 (hereafter the WSA), provides for democracy and inclusiveness in the water sector. ${ }^{29}$ It also provides for the management, conservation and protection of water resources. ${ }^{30}$

The WSA gives effect to the right to access to sufficient water guaranteed in section 27(1)(b) of the Constitution. The Constitution therefore provides the overarching legal framework for water security in South Africa. In terms of section 27 the State is obliged to take reasonable legislative and other

25 The Group Areas Act 41 of 1950, the Bantu Homelands Citizens Act 26 of 1970 and the Natives Land Act 27 of 1913 are a few of the Apartheid statutes which were aimed at segregating the races physically and limiting their access to basic resources, further perpetuating oppression.

26 Stein 2005 Tex L Rev 2168.

27 See in this regard Schedule 7 of the National Water Act 36 of 1998 (the NWA).

28 Gabru 2005 PELJ 22.

29 The author hereof contends that while the NWA seeks to protect water resources, the Water Services Act 108 of 1997 (the WSA) provides for the right to access to a basic water supply. These aims are mirrored in the components of water security, which means that to achieve the end goal, these statutes should be read together. Section 2 of the NWA. 
measures within its available resources to achieve the progressive realisation of the right of access to sufficient water. ${ }^{31}$ Under the Constitution, local government bears the direct responsibility to provide potable water to communities. ${ }^{32}$ A reading of the WSA $^{33}$ and the Local Government: Municipal Systems Act 32 of 2000 (hereafter the Systems Act) reveals that a municipality can provide water services or outsource the provision of water services to another institution. ${ }^{34}$ Bodies responsible for water services are known as water service institutions, including a water services authority, a water services provider, a water board and a water services committee. ${ }^{35} \mathrm{~A}$ water services intermediary also supplies water services to another, but this is done in a contract where the obligation to provide water services is incidental to the main object of that contract. ${ }^{36}$

Furthermore, the WSA states that water services must be provided in terms of certain conditions set by water services providers. ${ }^{37}$ These conditions must be accessible to the public and may not contradict any conditions for the provision of water services contained in bylaws made by the water services authority having jurisdiction in an area. ${ }^{38}$ These conditions must provide for the circumstances under which water services may be limited or discontinued and procedures for limiting or discontinuing water services. ${ }^{39}$ The WSA describes what a "basic water supply"40 means, but does not

31 Section 27(2) of the Constitution.

32 Section 156(1)(a) read with Schedule 4B of the Constitution; Fuo 2017 De Jure 328333.

33 Section 1 of the WSA.

34 Sections 76-81 of the Systems Act empowers municipalities to use an external mechanism to provide water services. In terms of section 76 of the Local Government: Municipal Systems Act 32 of 2000 (the Systems Act) a municipality may provide a municipal service in its area or a part of its area through external mechanisms by entering into a service delivery agreement with a municipal entity, another municipality, an organ of state, a community-based organisation or a NonGovernmental Organisation legally competent to enter into such an agreement, or any other person or institution legally competent to operate such activities. This section of the Act therefore provides for the outsourcing of water provision services to private individuals and companies.

35 Section 1 of the WSA.

36 Section 1 of the WSA.

37 Section $4(1)$ of the WSA.

38 Section 4(2)(a) and (b) of the WSA.

39 Section 4(2)(c) of the WSA. The Act expressly states that procedures for the limitation or discontinuation of water services must be fair and equitable. See $s$ 4(3) of the WSA in this regard.

40 Section 1 of the WSA. The prescribed minimum standard of water supply services necessary for the reliable supply of a sufficient quantity and quality of water to households, including informal households, to support life and personal hygiene. 
provide the minimum standard against which non-compliance can be measured. ${ }^{41}$

The 2001 Regulations Relating to Compulsory National Standards and Measures to Conserve Water ${ }^{42}$ (hereafter the 2001 Regulations) expands on the content of the right to a basic water supply. ${ }^{43}$ The 2001 Regulations describe the content of the right to basic water and quantify the minimum standard for basic water supply services to include the provision of education relevant to effective water use, and a minimum quantity of 25 litres of potable water per person per day, or 6 kilolitres per household per month. ${ }^{44}$

The NWA provides a framework in which water resources may be protected, conserved, developed and used. ${ }^{45}$ There are certain provisions that seek to protect the nation's water resources, of which the most important can be found in Chapter 3 of the NWA. Firstly, it requires the Minister to develop a classification system for water resources. ${ }^{46}$ Secondly, the Minister is required to use this system to determine the class and resource quality of the water resource. ${ }^{47}$ Finally, the Minister is required to determine the Reserve of a water resource. ${ }^{48}$ The Reserve is twofold and applies to both components of water security: the basic human needs Reserve and the ecological Reserve. ${ }^{49}$ By including the ecological Reserve as a core component in water management, the NWA attempts to create a balanced hydrological cycle, but also provides for priority water use, which strives to meet basic human needs and protect freshwater resources. ${ }^{50}$

41 See the interpretation of the minimum standard in the series of Mazibuko-decisions discussed below.

$42 \quad$ GN R509 in GG 22355 of 8 June 2001 (the 2001 Regulations).

43 Regulation 3 of the 2001 Regulations provides the minimum standard for basic water supply services as a minimum quantity of potable water of 25 litres per person per day, or 6 kilolitres per household per month, while regulation 4 requires a water services institution to take steps to ensure that where water services usually provided by or on behalf of that water services institution are interrupted for a period of more than 24 hours for reasons other than those contemplated in s 4 of the WSA, a consumer has access to alternative water services comprising at least 10 litres of potable water per person per day.

$44 \quad$ Regulation 3 of the 2001 Regulations.

45 Section 2 of the NWA.

46 Section 12 of the NWA.

47 Section 13 of the NWA.

48 Section 16 of the NWA.

49 Chapter 3, Part 3 of the NWA. The ecological Reserve relates to the water required to protect the aquatic ecosystems of the water resource. 
Other provisions in the NWA which speak to the notion of water security and specifically the protection of water resources are sections 19 and 20 of the Act. Section 19 echoes the environmental principles established in National Environmental Management Act 107 of 1998 (hereafter the NEMA), namely the polluter pays, preventative and remediation principles. This section states that an owner of land, a person in control of land, or a person who occupies or uses the land on which any activity or process is or was performed or undertaken which causes, who has caused or is likely to cause the pollution of a water resource must take all reasonable measures to prevent such pollution from occurring, continuing or recurring. ${ }^{51}$ The NWA also furnishes the measures that may be undertaken where the pollution of a water resource occurs. ${ }^{52}$

A Catchment Management Agency (CMA) is empowered to direct any person to take the measures provided or take the measures necessary to remedy the situation ${ }^{53}$ and thereafter may recover any costs incurred in taking such remedial measures. ${ }^{54}$ Similarly, in the event of an emergency incident a person responsible for the incident or the substance involved must report that incident to the Department of Water Affairs, the South African Police Services, the relevant fire department or the relevant CMA. Such a person must take all reasonable steps to minimise the effects of the incident, undertake clean-up procedures, remedy the effect of the incident and undertake any other measure required by the CMA in question within the specified time. ${ }^{55}$ The CMA is also empowered to take the steps necessary to remedy the situation and recover the costs thereof from the person responsible. ${ }^{56}$ In addition, the Minister must fulfil the role of the CMA in areas where no such agency has been established, or where an agency has been established but is not yet functional. ${ }^{57}$

Section 2(4)(d) of the NEMA requires the State to address past injustices that continue to limit equitable access to water resources. Certain

\footnotetext{
51 Section $19(1)$ of the NWA.

52 Section $19(2)$ of the NWA.

53 Sections 19(3) and (4) of the NWA.

54 Section $19(5)$ of the NWA.

55 Section $20(4)$ of the NWA.

56 Sections 20(6) and (7) of the NWA. Theoretically, granting catchment management agencies these compliance and enforcement powers should be fairly sufficient to address water pollution. However, there are practical issues which arise. Although the Act envisages the establishment of nine Catchment Management Agencies (CMAs), only two are currently functional, with the remaining seven being referred to as proto-CMAs as they are still in the process of being established. See Meissner et al "Establishment of Catchment Management Agencies" 19. 
governmental policies and strategies give practical effect to this legislation. The National Indigent Policy (2006) (hereafter the NIP), ${ }^{58}$ the Free Basic Water Implementation Strategy (2007) ${ }^{59}$ (hereafter FBWIS) and the National Water Resource Strategy (NWRS) form part of the policy framework on the provision and protection of water in South Africa.

From this brief exposition it is clear that the different components of water security require different regulatory instruments. The effectiveness of these instruments is tested in the courts, as will be seen below. However, it is important to establish what formalised functions the court has in executing and enforcing the rules.

\section{The mandate and duties of South African courts}

Chapter 8 of the Constitution governs the South African judiciary. In terms of section 165 of the Constitution, the judicial authority of the Republic vests in the courts. ${ }^{60}$ The courts are independent, subject only to the Constitution and the law, ${ }^{61}$ and no organ of state may interfere with their functioning. ${ }^{62}$ Any order issued by a court binds all persons and organs of state to which

DPLG 2006 https://www.westerncape.gov.za/text/2012/11/national_framework for_municipal_indigent_policies.pdf accessed 20 October 2017 (the NIP) 2. The NIP was adopted by national government to consolidate several basic services policies and provides a framework for the provision of free basic services to impoverished people. The NIP, which is the policy which municipalities must adopt and alter according to their merits, empowers the municipality to provide free potable water to households which have been identified as indigent households in terms of the policy. This means that marginalised persons will obtain free water supply services from the municipality, which will in turn guarantee access to potable water. The NIP proposes this system as one mechanism of ensuring financial stability, but the method cannot be applied across the board in every municipal indigent policy, as municipalities have the right to decide on which mechanisms to implement according to their particular circumstances. See NIP 28-30. The High Court found that 25 litres of potable water per person per day is insufficient to meet the basic needs and ordered that an amount of 50 litres would thus be sufficient to meet those needs. This decision was overturned in the superior courts in Mazibuko, where the Court consequently refused to provide for the normative content of the right to water, as this fell outside the scope of the judiciary. See Mazibuko $v$ City of Johannesburg $2008 \mathrm{JOL} 21829$ (W) para 183.

59 Department of Water Affairs 2003 https://www.dwa.gov.za/Documents/Policies/ Strategic\%20Framework\%20approved.pdf (the FBWIS). The FBWIS promotes sustainable access to basic water supply by providing a subsidy for the ongoing operating and maintenance cost of a basic water supply service. See Swart and Adams "Water Services Provision" 459.

60 Section 165(1) of the Constitution.

61 Section 165(2) of the Constitution.

62 Section 165(3) of the Constitution. The independence of the judiciary and the challenges which this notion poses for judges were discussed by Judge Van Zyl in his 2008 FW De Klerk Lecture. In this regard see Van Zyl 2008 PELJ 1-13. 
it applies. ${ }^{63}$ This provision emphasises the independence of the courts, the principle of the separation of powers, the supremacy of the Constitution, and the fact that the State and its citizens should submit to the judgments made by the courts. ${ }^{64}$

Section 172(1)(a) of the Constitution provides that, when deciding a constitutional matter within its power, a court must declare that any law or conduct that is inconsistent with the Constitution is invalid to the extent of its inconsistency. Upon a finding of constitutional invalidity, a court may make any order that is just and equitable, including an order limiting the retrospective effect of a declaration of invalidity, ${ }^{65}$ or an order suspending the declaration of invalidity to allow the competent authority time to correct the defect. ${ }^{66}$ A court may grant a temporary interdict or other temporary relief to a party in the interim or may adjourn the proceedings, pending confirmation of constitutional invalidity from the Constitutional Court. ${ }^{67}$ Section 172 grants the Constitutional Court wide discretionary powers, in that any court order concerning the constitutional validity of an Act of Parliament or conduct will not be binding until it is confirmed by the Constitutional Court. This has considerable ramifications for water security law, as the Constitutional Court may declare invalid conduct based on any of the two components of water security which the writer has identified, and therefore promote water security through judicial processes.

Apart from the provisions dealing with the structure and powers of courts in South Africa, there are many provisions in the Constitution that facilitate access to courts. In section 38 the Constitution makes provision for parties who are competent to approach the court. The section states that the listed parties have the right to approach a competent court where a right in the Bill of Rights has allegedly been violated, and such a competent court may grant appropriate relief, including a declaration of rights. ${ }^{68}$ Parties who may approach a court include anyone acting in his or her interest or on behalf of another person who cannot act in his or her name, anyone acting as a member of or in the interest of a group of persons, anyone acting in the

63 Section 165(5) of the Constitution.

64 Kotzé and Du Plessis 2010 Journal of Court Innovation 160-161. Also see Budlender 2011 SAJHR 582-599 for commentary regarding the role of the Constitutional Court in asserting democracy, and specifically on the author's views on the supervisory role of the court in the human rights paradigm.

65 Section 172(1)(b)(i) of the Constitution.

66 Section 172(1)(b)(ii) of the Constitution.

67 Section 172(2)(b) of the Constitution.

68 Section 38 of the Constitution. 
public interest and an association acting in the interest of its members. ${ }^{69}$ The effect of this provision on issues related to water security is that vulnerable persons who usually do not have access to the courts may be represented by an interested party such as an Non-Governmental Organisation (NGO), who may advocate for their rights. It creates a doorway for the enforcement of rights through a party acting in the best interests of the affected group. ${ }^{70}$

In a study examining the role of courts in promoting sustainable development in South Africa, Kotzé and Du Plessis argue that the role of the courts is four-fold:

\begin{abstract}
First courts 'uphold' the law in practice by weighing rights and interests and then (hopefully) making reasonable, just, lawful and equitable findings; second, courts solve environmental disputes between parties by interpreting and then applying the law and in this sense, they give practical effect to one of the most basic functions of law, namely, that of social control and maintaining social order; third, while executing all their functions in terms of the previous two roles, courts simultaneously contribute, through analysis, interpretation and explanation, to a sounder and more useful, or refined, comprehension, and therefore, deepening of the environmental law discourse; and fourth, by doing so, the courts contribute to law-making. ${ }^{71}$
\end{abstract}

Drawing from the views of Kotzé and Du Plessis outlined in the above extract, this researcher argues that South African courts can promote water security by discharging four duties. Firstly, the courts must uphold the law by weighing the rights and interests that relate to water and then making reasonable, just and equitable findings. Secondly, the courts must solve water-related disputes between parties by interpreting and applying the Constitution, water legislation and policies discussed in part three above. Just as in the sustainable development context, it is submitted that in executing the first two functions, courts contribute to a deeper understanding of the water security discourse through analysis, interpretation and explanation. Finally, through the execution of their traditional function courts contribute to law-making that has a direct effect on the development of water security law. The breadth of the discretionary powers entrusted to courts by the Constitution suggests that in principle they

\footnotetext{
$69 \quad$ Section 38 of the Constitution.

70 Cote and Van Garderen comment on the usefulness and effectiveness of $\mathrm{s} 38$ to the NGO, Lawyers for Human Rights, who litigate in the sphere of human rights on behalf of very poor, often displaced persons. See Cote and Van Garderen 2011 SAJHR 171. 
can contribute towards promoting water security by executing the roles identified above.

In the litigation of socio-economic rights and in cases where an organ of state has failed to fulfil its constitutional mandate, courts have relied on the use of structural interdicts to supervise the execution of a court order and the State's actions. ${ }^{72}$ Structural interdicts have been employed as a mechanism to supervise conduct and prevent further violations of fundamental rights in cases such as Kenton on Sea Ratepayers Association $\checkmark$ Ndlambe Local Municipality ${ }^{73}$ as well as National Treasury $v$ Opposition to Urban Tolling Alliance. ${ }^{74}$ In the latter the court stated that a structural interdict may be an appropriate remedy when a constitutional right has been breached, since it can remedy the breach by instructing the violator to take certain steps to firstly comply with its obligations and consequently to report back to court on the extent to which it has adhered to the court's order. ${ }^{75}$ These duties encompass the use of necessary measures such as supervisory interdicts and sanctions and penalties prescribed by criminal laws, as illustrated by the case discussions below.

\section{A critical analysis of case law}

The courts have had a few opportunities to engage in water security issues. In this part, two cases will be analysed where the court adjudicated on these issues, focussing on the specific components of water security. For sustainable and affordable access to water, the Federation for Sustainable Environment $v$ Minister of Water ${ }^{76}$ and the Mazibuko $v$ City of Johannesburg ${ }^{77}$ cases are examined. In addition, the criminal matter of $S v$ Blue Platinum Ventures 16 (Pty) Ltd and Matome Samuel Maponya ${ }^{78}$ is analysed for the protection of resources.

72 Viljoen and Makama 2018 SAJHR 212.

73 Kenton on Sea Ratepayers Association v Ndlambe Local Municipality 20172 SA 86 (ECG).

$74 \quad$ National Treasury v Opposition to Urban Tolling Alliance 20126 SA 223 (C).

75 National Treasury v Opposition to Urban Tolling Alliance 20126 SA 223 (C) paras 95-96.

76 Federation for Sustainable Environment v Minister of Water Affairs (35672/12) [2012] ZAGPPHC 128 (10 July 2012) (hereafter Federation for Sustainable Environment case).

$77 \quad$ Mazibuko v City of Johannesburg 20104 SA 1 (CC).

78 S v Blue Platinum Ventures 16 (Pty) Ltd and Matome Samuel Maponya (Sentencing Proceedings) (Naphuno Regional Magistrates' Court) (unreported) case number RN126/13 of 9 January 2014 (hereafter the Blue Platinum case). 


\subsection{Federation for Sustainable Environment $v$ Minister of Water Affairs $^{79}$}

The Silobela community lies on the outskirts of Carolina in Mpumalanga. ${ }^{80}$ The water supply in the area was contaminated by acid mine water, making the water unfit for human consumption. 81 To alleviate the situation, in February 2012, water tanks were sourced by the local municipality to supply the residents with water from neighbouring towns. Approximately 20 water tanks were placed around the area of Silobela, Carolina. ${ }^{82}$ The applicant alleged that for the period between March and May 2012 the system of providing water to the residents was inadequate as some of the tanks had not been refilled and others remained empty. ${ }^{83}$ The applicant submitted the following arguments to the court: firstly, that the residents of Carolina had not had a reliable supply of water for an extended period beyond the seven days as prescribed by the 2001 Regulations, ${ }^{84}$ which constituted a gross infringement of the constitutional right to access to water. ${ }^{85}$ Secondly, the respondents should engage with the community in putting measures in place that would address water provision and the mitigation and prevention of pollution by the mines. ${ }^{86}$ Finally, the applicant argued that the matter was one of urgency. ${ }^{87}$

The Court first dealt with the issue of urgency and held that due to the water supply being dire at that moment, the matter was one of urgency, ${ }^{88}$ referring to the structural racial divide caused by the effects of Apartheid. Furthermore, it held that the nature of the case required that it be dealt with urgently as it related to the fundamentally entrenched right to access to water. ${ }^{89}$ In the light of this urgency, the Court ordered that the municipality provide temporary potable water to the residents of the affected communities in line with the 2001 Regulations. ${ }^{90}$

\footnotetext{
Federation for Sustainable Environment case.

Federation for Sustainable Environment case para 3.

Federation for Sustainable Environment case para 4.

Federation for Sustainable Environment case para 4.

Federation for Sustainable Environment case para 5.

Federation for Sustainable Environment case para 6.

Federation for Sustainable Environment case para 6.

Federation for Sustainable Environment case para 7.

Federation for Sustainable Environment case para 8.

Federation for Sustainable Environment case para 8.

Federation for Sustainable Environment case para 18.

Federation for Sustainable Environment case paras 26(1)-(2).
} 
The Court acknowledged the duties of the respondents in ensuring water supply, as envisaged by the Constitution and relevant statutes. ${ }^{91}$ However, the Court stated that the failure to provide access by way of the water tanks could not be the sole responsibility of the respondents, as it had been submitted that some of the water tanks had been destroyed by the residents of Silobela, ${ }^{92}$ rendering positive action by the respondents ineffective. In addressing the argument regarding community engagement, the Court ordered that the municipality must engage with the residents regarding the steps to be taken in ensuring that potable water can be supplied through the water supply services, and the intricacies of the temporary water provision, such as the quantity and location of such supply..$^{93}$ The Court emphasised the duty of the municipality to solve the water crisis and engage with community members in a meaningful manner in developing a progressive plan to achieve this objective. ${ }^{94}$ The municipality was finally ordered to report back to the Court within a month of the court's order as to the measures taken to ensure that potable water was supplied to the affected communities through the water services institution. ${ }^{95}$

\subsubsection{A critical reflection on the judgment}

As a starting point, it must be noted that the municipality failed to comply with the court order in that the water tanks were not filled consistently, and eventually this supply was stopped. ${ }^{96}$ The water crisis was eventually resolved without an appeal to the Supreme Court of Appeal. In terms of the 2001 Regulations, the conduct of the municipality was declared unlawful due to its failure to provide access to effective and reliable potable water. ${ }^{97}$ This action by the Court resulted in the municipality's effectively upholding the law, discharging one of its duties as identified above. Further, by ordering a temporary restoration of access to potable water within 24 hours, in line with the 2001 Regulations, ${ }^{98}$ and directing the municipality to engage actively and meaningfully with the community on the steps which it intended to take to make such access to potable water services permanent, ${ }^{99}$ the Court ensured sustainable access to water services - a core component of

91 Federation for Sustainable Environment case paras 10-15.

92 Federation for Sustainable Environment case para 22.

93 Federation for Sustainable Environment case para 26(3).

$94 \quad$ Federation for Sustainable Environment case para 24.

95 Federation for Sustainable Environment case para 26(4).

96 Fuo 2013 Murdoch $U L$ Rev 31. In this regard also see Lawyers for Human Rights 2012 http://www.Ihr.org.za/news/2012/press-release-carolina-residents-opposemunicipalities-leave-appeal-application.

$97 \quad$ Federation for Sustainable Environment case para 2.

$98 \quad$ Federation for Sustainable Environment case para 3.

$99 \quad$ Federation for Sustainable Environment case para 4. 
water security. The Court accepted the matter as one of urgency, which confirms the position of the Court in placing value on the interests of society, especially where it is alleged that a violation of a constitutionally entrenched right has occurred.

The order made by the Court requiring the local authority to report within a month of the order being issued placed the Court in a supervisory role in this regard. Fuo 100 believes that the use of supervisory interdicts demonstrates the commitment of courts to improving the lives of impoverished, disadvantaged and often marginalised South Africans. The order also held the local authority responsible and thereby forced it to discharge its socio-economic duties. ${ }^{101}$ In considering Fuo's argument on supervisory interdicts, their use in the water security context can be important, as it has been established above that the poor and marginalised are most affected by water insecurity, and that municipalities are failing to deliver this vital service. This failure places the courts in a position to assist indigents through granting supervisory interdicts and ultimately supervising and assisting local authorities to fulfil their service delivery mandate. However, supervisory interdicts can also create unnecessary complications in terms of the principle of separation of powers. Because it is a subjective form of relief, in that the terms of the order may differ from case to case, it should be used with caution, as it may interfere with an institution's autonomy.

\subsection{Mazibuko v City of Johannesburg ${ }^{102}$}

The Mazibuko matter is the landmark case concerning access to water in South Africa. The matter, which was first heard in the High Court and culminated in a constitutional court judgment, is crucial in this discussion. The issues arising from the judgment of the court a quo up until the judgment handed down by the constitutional court are analysed. All of the applicants in this matter were residents of one of the poorest areas of the City of Johannesburg (the respondent). ${ }^{103}$ Water leakages in the City of Johannesburg had become a problem, and the area in which the applicants resided, Phiri in Soweto, had a large quantity of water which was unaccounted for due to leakages and to the fact that many residents had not paid the consumption charges. ${ }^{104}$ Therefore, a project to curb water

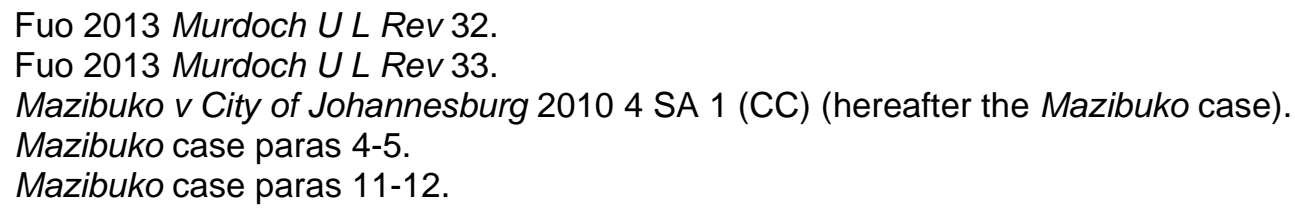


leakages and increase rates collection was launched. ${ }^{105}$ As part of the project, prepaid water meters were installed in selected households in the area. $^{106}$

The Mazibuko case was first heard in the High Court and challenged the legality of installing prepaid water meters in light of the constitutional right to access to sufficient water. ${ }^{107}$ The case investigated the obligations of the City of Johannesburg and Johannesburg Water regarding access to water and the supply of free water for residents who cannot afford to pay. It was argued that since pre-payment water meters require users to pay for water in advance, access to sufficient water is limited if users cannot afford to pay in advance. This was the reality faced by the Phiri residents. It was argued that this was incompatible with the constitutional right to sufficient water. ${ }^{108}$

The High Court held that the installation of pre-payment meters was a retrogressive step, in that it not only hampered the applicants' access to water but also in that they were forcefully installed without the consent of and input from the residents themselves. The installation was therefore unconstitutional and unlawful. ${ }^{109}$ Furthermore, the Court held that, given the particular needs of the Phiri community, a volume of 50 litres of water per day would be a more appropriate quantification of sufficient water than the statutory 25 litres per day limit. ${ }^{110}$ Satisfied that the respondent could provide this increased amount, the High Court ruled in the applicants' favour. ${ }^{111}$ The Court also found that the various policies adopted by the City, especially the policies encouraging and promoting the installation of these prepaid water meters, were irrational and unreasonable. ${ }^{112}$

Dissatisfied with the High Court's judgment, the City of Johannesburg escalated the matter to the Supreme Court of Appeal. ${ }^{113}$ The Court had to address two main issues, namely whether the City had a constitutional mandate to provide free water to the residents who could not afford to pay for such water, and whether the City could restrict the Phiri residents' access to water by way of pre-payment water meters. The Court held, after

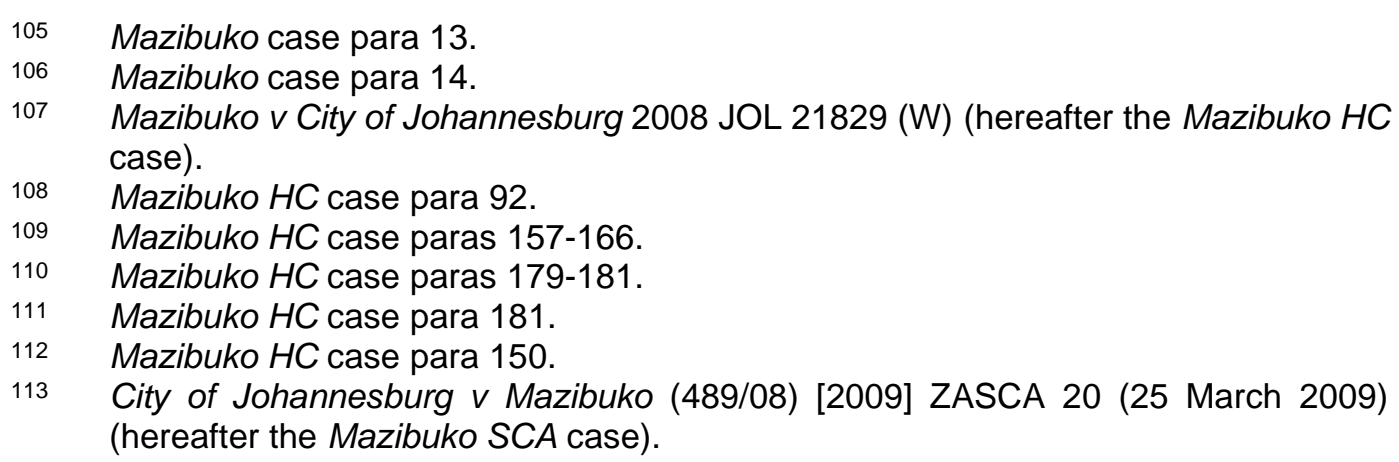


investigation, that 42 litres of water per person per day would be sufficient. ${ }^{114}$ It was found that the City was constitutionally obliged to grant each Phiri resident who could not afford to pay for water 42 litres per day free, insofar as this could reasonably be done with due consideration to the available resources. ${ }^{115}$ The matter was referred back to the City to reformulate its water policy in accord with the ruling. ${ }^{116}$

\subsubsection{Mazibuko v City of Johannesburg ${ }^{117}$}

Unhappy with the Supreme Court's decision to reduce the amount deemed sufficient from 50 litres per day to 42 litres per day, the residents of Phiri appealed to the Constitutional Court. The applicants challenged the constitutionality of the City's decision to supply an amount of 6 kilolitres of free water per month to every accountholder in the City on the ground that the policy from which it stemmed conflicted with section $27(1)(b)$ of the Constitution. ${ }^{118}$ The applicants argued that the court should determine the content of the right in section $27(1)$ (b) by quantifying the amount of water that could be considered sufficient for a dignified life. They argued that 50 litres per person per day would meet this threshold. ${ }^{119}$ The applicants also argued that the City's installation of water meters was unlawful. ${ }^{120}$ The questions that arose pertained to the nature of the City's obligations to provide access to sufficient water in terms of the Constitution.

The Court had to assess the extent of the State's positive obligations in terms of section $27(1)$ (b) of the Constitution. In doing so, the Court followed the same approach as was followed in the Government of the Republic of South Africa $v$ Grootboom ${ }^{121}$ and Minister of Health $v$ Treatment Action Campaign $^{122}$ cases. In these cases the Constitutional Court held that the Constitution provides qualifying provisions for section 26 and 27 which place a direct duty on the State to progressively realise these rights. ${ }^{123}$ It was held that section 27(1)(b) of the Constitution does not require the State to provide every person with water on demand, but rather that it requires the State to

\footnotetext{
114 Mazibuko SCA case paras 22-24.

115 Mazibuko SCA case para 43.

116 Mazibuko SCA case para 62.

117 The Mazibuko case.

118 Mazibuko case para 6.

119 Mazibuko case para 51

$120 \quad$ Mazibuko case para 6.

121 Government of the Republic of South Africa v Grootboom 20011 SA 46 (CC) (hereafter the Grootboom case).

122 Minister of Health v Treatment Action Campaign 20025 SA 721 (CC) (hereafter the Treatment Action Campaign case).

123 Mazibuko case paras 48-49.
} 
take reasonable legislative and other measures to progressively realise the right of access to sufficient water within the State's available resources. ${ }^{124}$

Concerning the argument raised by the applicants that the Court should determine the content of the right contained in section 27(1)(b) of the Constitution, the Court rejected this argument on two grounds. Firstly, the Court stated that section 27(1)(b) and section 27(2) must be read together, in that the Constitution is clear that the right to access to sufficient water cannot be realised on demand but must be realised progressively, taking into consideration several factors. ${ }^{125}$ The content of the right will vary over time and context. Quantifying the right will prevent analysis of the context in future and lead to a situation where no progress in terms of realising the right is made. ${ }^{126}$ Secondly, the Court held that it is inappropriate for the judiciary to determine exactly what the achievement of socio-economic rights entails. It must be left to the executive and legislature, working in conjunction with state institutions and the consideration of budget allowance and forecasts. ${ }^{127}$ The Court reasoned that the Constitution prescribes that legislative and other measures will be the instrument for achieving socioeconomic rights. It held that when the State adopts such measures, the rights in the Constitution acquire content, and that content will then be subject to the constitutional standard of reasonableness. ${ }^{128}$

The Court also explained how the positive obligations that rest upon the State would be enforced by the courts:

Thus the positive obligations imposed upon government by the social and economic rights in our Constitution will be enforced by courts in at least the following ways. If government takes no steps to realise the rights, the courts will require government to take steps. If government's adopted measures are unreasonable, the courts will similarly require that they are reviewed to meet the constitutional standard of reasonableness. From Grootboom, it is clear that a measure will be unreasonable if it makes no provision for those most desperately in need. If government adopts a policy with unreasonable limitations or exclusions, as in Treatment Action Campaign (No 2), the Court may order that those are removed. Finally, the obligation of progressive realisation imposes a duty upon government continually to review its policies to ensure that the achievement of the right is progressively realised. ${ }^{129}$

The Court rejected the arguments made by the applicants claiming that the City's policy was unconstitutional based on the fact that the amount of 6

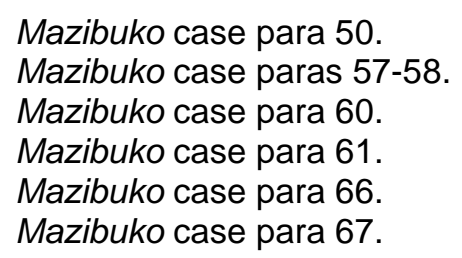


kilolitres of water was insufficient for large households, ${ }^{130}$ and that the policy was inflexible in that it allocated 6 kilolitres of water to both rich and poor households, ${ }^{131}$ and finally, that it allocated water per household rather than per person. ${ }^{132}$ The Court consequently found that the City's Free Basic Water Policy fell within the bounds of reasonableness and therefore did not contravene either section 27 of the Constitution or the WSA. ${ }^{133}$

On the pre-paid water meters issue, the Court held that the City was authorised to introduce pre-paid meters in terms of national legislation and the City's by-laws. ${ }^{134}$ Judge O'Regan stated that the power to install prepaid meters was reasonably incidental to providing services to citizens in a sustainable manner, and was a power that was reasonably incidental to the effective performance and functioning of a municipality. ${ }^{135}$ The Court also held that where the water supply ceased, pending the purchase of additional credit, this should be understood as a temporary suspension and not a discontinuation of services. ${ }^{136}$ In effect, the Court held that the installation of prepaid water meters was neither unconstitutional nor in conflict with the WSA, and thus it was lawful. ${ }^{137}$ The Court also praised the City for its continuous revision of its policy, which addressed the needs of the poorest residents, and could not find that the policy was unreasonable, as claimed by the applicants. ${ }^{138}$

\subsubsection{A critical reflection on the judgments}

The role of the Court in the Mazibuko case is vital to a consideration of socio-economic rights jurisprudence in South Africa. The case has drawn much criticism from scholars and will undoubtedly remain the point of reference in the search for water security. In part five above, it was indicated that one crucial role courts play is to balance the competing interests of society and to make judgments that are just and equitable. This case tested that benchmark in its entirety and the criticism that followed proves this. The Constitutional Court was put in the position of weighing up the interests of the poor, marginalised residents of Phiri against the City's desire to rehabilitate the financial system it uses to provide water services. This is an

\footnotetext{
Mazibuko case paras 86-89.

Mazibuko case para 83.

Mazibuko case para 84.

Mazibuko case paras 138-143.

Mazibuko case paras 106-114.

Mazibuko case para 111.

Mazibuko case para 120.

Mazibuko case para 158.

Mazibuko case para 143.
} 
example of the conflict involved in attaining sustainability. The social aspects in this matter could be assumed to outweigh the economic challenges faced by the City. Kotzé ${ }^{139}$ makes the same analogy regarding sustainability and praises the Constitutional Court's judgment. He places intergenerational equity at the heart of the Court's decision, by stating that due to the severe water scarcity issues experienced by South Africa, the Court could not provide every resident of Phiri with access to 50 litres of water per day. In his critique Kotzé also alludes to the Court's role in the interpretation of the law, stating that a "conservative approach to the interpretation of certain socio-economic rights may allow for the possibility of protecting natural resources through the imposition of constraints or limitations on resource use provided by the concept of sustainability". ${ }^{140}$ This means that section 27 of the Constitution may be utilised not only to regulate access to water but also as a means of protecting water resources for posterity. ${ }^{141}$

Dugard and Mohlakoana argue that women suffer the most when it comes to access to water. Firstly, access to water is still unaffordable for many women-headed households, ${ }^{142}$ and women often endure most of the problems that accompany the installation of prepaid meters, such as disconnections due to the exhaustion of their credit. ${ }^{143}$ However, this argument was never raised in the appeals in the Supreme Court and the Constitutional Court. ${ }^{144}$ The author argues that had this aspect of access been argued well before the Court, it might have influenced the outcome to the benefit of the poor women who tirelessly labour in rural areas to fetch water. The Court's assertion that where the water supply of a resident has ceased, this should be considered a temporary suspension fails to consider the disparity and inequality that exists in this community, as well as the many other informal, vulnerable settlements in South Africa which Phiri represents. A mere temporary suspension would immediately result in a discontinuation of services if the residents in question cannot afford to reinstate their services for financial reasons. There is nothing temporary about this and it is quite reckless in the face of those who struggle to make ends meet.

\footnotetext{
139 Kotzé 2010 Journal of Human Rights and the Environment 158.

140 Kotzé 2010 Journal of Human Rights and the Environment 159.

141 Kotzé 2010 Journal of Human Rights and the Environment 159.

142 Dugard and Maohlakoana 2009 SAJHR 550, 561.

143 Dugard and Maohlakoana 2009 SAJHR 564-565.

144 Dugard and Maohlakoana 2009 SAJHR 557.
} 
According to Dugard the Mazibuko case reveals a clash between a rightsbased concept of water as a social good against an approach where water is viewed as a commodity. ${ }^{145}$ In the matter before the High Court the applicants had introduced a new model, which was adopted by the High Court. ${ }^{146}$ This rights-based approach would satisfy the needs of the poor while meeting municipal cost-recovery requirements and eliminating excessive water use, but the reasoning of the High Court had not been followed by the Constitutional Court. ${ }^{147}$ The Court was very cautious in interfering with the duties of the executive and legislature in that it refused to make a call on the content of section 27 , electing instead to play a role in solving the dispute at hand by interpreting and applying the Constitution as well as the City's policy regarding the provision of water. ${ }^{148}$ In this manner the Constitutional Court addressed sustainable access to water services as a core component of water security in that it praised the efforts of the municipality to continuously revise the City's Free Basic Water Policy ${ }^{149}$ and ensure that residents had access to water services considering the changing circumstances based as forecast on its continuous research in this regard. The City's move to install prepaid water meters was aligned with its policy relating to the provision of access to water services, which is what the Court took cognisance of when interpreting the policy. The City, according to the Court, had upheld its duty in terms of section 27(2) to take reasonable legislative and other steps to progressively realise the right to access to sufficient water as envisioned by section 27(1)(b), by implementing the City's Free Basic Water Policy.

The jurisprudence of the Court in the Mazibuko case contributed to a deeper understanding of the water security discourse in South Africa, especially in the light of the Constitution and the duties it imposes on the State to realise socio-economic rights. It was held that the right to access to water cannot be enforced on demand and that the State needs to develop reasonable legislative and other measures to realise this right. In this case, one of the reasonable measures was the implementation of the City's Free Basic Water Policy, which was in a constant state of revision, as the indigent

\footnotetext{
145 Dugard 2010 Review of Radical Political Economics 177.

146 Dugard 2010 Review of Radical Political Economics 177.

147 Dugard 2010 Review of Radical Political Economics 177.

148 Brand describes this sense of hesitation as a strategy of deference, whereby a court simply defers the issues which require a decision to one of the other branches of government. He further criticises this judicial deference as limiting the political capacity of poor people, and therefore further impoverishing them. This affects their claim to socio-economic rights and their ability to approach the courts for remedy. See Brand 2011 Stell LR 619-628. 
profile of the City changed. Humby and Grandbois ${ }^{150}$ criticise the Constitutional Court as having failed in its duty to enforce the human right to water and ask whether the Court in this matter should have scrutinised the legal, institutional and financial context in which local authorities operate as water services providers. ${ }^{151}$ This author shares the point of view implicit here. However, the financial and institutional context in which a municipality operates cannot be a matter which the Court alone must consider, as it is closely related to the political climate of South Africa.

In assessing the Court's role to uphold the law by weighing the interest of society and making just and equitable findings, and in considering the critique of the judgment as well as the scope and theme of this research, this researcher is of the opinion that the Court in Mazibuko made a just and equitable finding regarding the lawfulness of the installation of prepaid meters. This action from the City was in keeping with its policies and its constitutional mandate to progressively realise the right to access to water and to take steps to realise that right. This would also ensure sustainable access to water services, which is very important when considering the notion of sustainability, the goals attached to it and the potential impact of climate change. The idea that water may be prepaid does not, in the author's opinion, equate to affordable access to water services. The situation in which the Phiri residents found themselves is a testament to that. Whether the residents had access to water through the prepaid meters or the conventional municipal system, disconnection was inevitable. Residents would then have to go through the process of having the system reconnected, which had its financial implications. If the conventional system were in operation and the water bill was not paid, the water would continue to flow. Although the prepaid method of regulating access was now part of the City's policy, which the Court described as being progressive and constantly evolving, in terms of the law it would also have to be subject to improvements. Irrespective of the fact that the Court discharged its role above, the author hereof is of the view that the court did not promote water security in this case, because the access component of the principle did not receive the judicial attention which it so deserved. When viewed in isolation, the socio-economic interests of the Phiri community were not sufficiently weighed against the benefits of a policy that at the core was purposed to serve the people.

\footnotetext{
$150 \quad$ Humby and Grandbois 2010 Les Cahiers de Droit 538.

151 Humby and Grandbois 2010 Les Cahiers de Droit 540.
} 
The Constitutional Court was extremely calculated in its approach to the issues presented by the Phiri residents. It erred on the side of caution so as not to act beyond its capabilities and reach a decision that would uncover an argument based on the separation of powers principle. However, this cautious approach let down the residents of Phiri. The Court shifted the focus of the case away from the residents themselves, and instead focussed on the City's obligations, without applying the context of the applicants before the court. In the end, the people of the Phiri community were still left without access to water, with no concrete solution to the problem created by the City's policy, which was highly praised by the Court. The human element of water security was not honoured, and thus the Constitutional Court in the Mazibuko judgement did not promote water security.

\subsection{S v Blue Platinum Ventures 16 (Pty) Ltd and Matome Samuel Maponya $^{152}$}

The accused and his company, Blue Platinum Ventures, had applied to the then Department of Mineral Resources, the Department of Water Affairs and the Department of Environmental Affairs and Tourism for the authorisations to undertake clay mining near Bathlabine Village. ${ }^{153}$ The mining occurred in close vicinity to a large river. ${ }^{154}$ The documentation which the accused submitted with his application for authorisation was incomplete, a fact of which he was informed by experts, yet he neglected to rectify the same. ${ }^{155}$ When the accused and his company continued with the mining despite not having received proper authorisation, the community appealed to the Department of Mineral Resources to take action against the company, but with no success. ${ }^{156}$ The company had also neglected to rehabilitate the area in which it mined. The community then laid criminal charges against the director and the company for causing environmental degradation. ${ }^{157}$

The accused pleaded guilty to the charges brought against him in terms of section 112 of the Criminal Procedure Act 51 of 1977, leaving the Court to determine the appropriate sentence to be imposed on the accused and his company. ${ }^{158}$ The state prosecutor contended that the accused should be

\footnotetext{
152 The Blue Platinum case.

153 Blue Platinum case 5.

154 Blue Platinum case 7.

155 Blue Platinum case 5.

156 Creamer Media Reporter 2014 http://m.miningweekly.com/article/mining-companydirector-receives-five-year-suspended-sentence-for-environmental-offences-alandmark-victory-for-the-centre-for-environmental-rights-2014-02-07/rep_id:3861.

157 Truter 2014 https://www.werksmans.com/legal-briefs-view/environmental-lawcompliance-noose-tightening/.

158 Blue Platinum case 2.
} 
sentenced according to section 24F of the NEMA, ${ }^{159}$ which imposes penalties for the offence committed. ${ }^{160}$ In mitigation of sentence, the accused pleaded the following: that his company, Blue Platinum, was no longer functional and therefore not profitable; that he was married and had children who were financially dependent on him; and finally, that he had offered to rehabilitate the mined area. ${ }^{161}$ The accused further stated that he could afford to pay a penalty amounting to R20 000.162

The state argued that the offence of which the accused's company had been convicted was profoundly serious. Aggravating factors which the public prosecutor argued included the fact that the mining activities had taken place next to a residential area and many houses had been left exposed to the pollution as a result of the conduct of the accused's company; the activity had resulted in serious soil erosion in these areas; the license which the accused had managed to obtain had already lapsed by the time he had commenced with mining activities; and the accused and his company had benefitted financially from the offence they had committed. ${ }^{163}$ The prosecutor also stressed that the accused could not simply start rehabilitation on his own, but that the rehabilitation had to comply with the Mineral and Petroleum Resources Development Act regulations and the Department of Mineral Resources guidelines. ${ }^{164}$ The maximum penalty prescribed by the NEMA amounted to $\mathrm{R} 5$ million, but the quantum required for the rehabilitation process was to be determined by the Department of Mineral Resources, which was a financial cost separate from the prescribed penalty. ${ }^{165}$

In handing down the sentence the magistrate affirmed that the offence was very serious and noted the "dire need" for the accused to start the rehabilitation process. ${ }^{166}$ The Court considered the fact that a payment of R5 million would benefit only the Department of Justice and the affected

159 Section 27F of the National Environmental Management Act 107 of 1998 (NEMA) states that no person may (a) commence an activity listed or specified in terms of $s$ $24(2)(a)$ or (b) unless the competent authority or the Minister responsible for mineral resources, as the case may be, has granted an environmental authorisation for the activity; or (b) commence and continue an activity listed in terms of s 24(2)(d) unless it is done in terms of an applicable norm or standard.

160 Blue Platinum case 7.

161 Blue Platinum case 2-4.

162 Blue Platinum case 14.

163 Blue Platinum case 6-8.

164 Blue Platinum case 6-7.

165 Blue Platinum case 10-11.

166 Blue Platinum case 24. 
residents would continue to suffer from the effects of the offence. ${ }^{167}$ An appropriate sentence would be one which promoted deterrence from committing the same offence while at the same time benefitting the community. ${ }^{168}$ Taking into account these considerations the court accordingly handed down a prison sentence of 5 years, suspended on the condition that the accused would not be convicted of contravening section $24 \mathrm{~F}$ of the NEMA during the period of suspension; and ruled that the accused had to rehabilitate all the areas affected by the mining operations within a set period. ${ }^{169}$ The estimated cost of rehabilitating the area amounted to 6.8 million Rands. ${ }^{170}$

The Court also had to determine whether the accused had derived a benefit from the offence that could be subject to confiscation under the Prevention of Organised Crime Act 121 of $1998 .{ }^{171}$ The defendants in this matter acknowledged that he had benefitted from the offence of which he had been convicted and that the Department of Environmental Affairs had suffered a loss of R200 000 because of the offence. ${ }^{172}$ The confiscation order of R200 000 payable to the state was thus handed down.

\subsubsection{A critical reflection on the judgment}

The Blue Platinum case has been praised as a landmark case that reflects the direction environmental enforcement should take in South Africa and is the first of its kind to hold a director of a company criminally liable in the context of environmental protection. Although the case does not create judicial precedent because of the status of the Magistrates Court, the ruling of the Court did open the doors to finally holding executives of companies personally liable under environmental legislation, and to future prosecutions for environmental offences.

The Court discharged its duty of solving a water-related dispute by interpreting and applying the laws found in legislation and policies through the sentence which was handed down under the provisions of the NEMA. In doing so the court's judgment and sentence had the following effect on

\footnotetext{
167 Blue Platinum case 24-25.

168 Blue Platinum case 25.

169 Blue Platinum case 26.

170 Truter 2014 https://www.werksmans.com/legal-briefs-view/environmental-lawcompliance-noose-tightening/.

171 Blue Platinum case 17.

172 NDPP v Blue Platinum Ventures 16 Pty Ltd and Matome Samuel Maponya: In re S $\checkmark$ Blue Platinum Ventures 16 (Pty) Ltd and Matome Samuel Maponya (Confiscation Order) (Naphuno Regional Magistrates' Court) (unreported) case number RN126/13 of 21 November 2014.
} 
environmental litigation: Firstly, the prosecution of environmental crimes remains at a minimum, so this matter has allowed the court to make a strong statement regarding the seriousness of environmental degradation as a criminal offence, particularly given the sentence, which was handed down, as well as the confiscation order. Secondly, the requirements imposed by legislation, that companies should have sound and effective environmental management systems which are monitored and enforced, were highlighted. This speaks to the benchmark in part four above, that states that Court's should develop the law. Thirdly, communities that are affected by the damage caused by large corporates are, because of the outcome of this case, encouraged and empowered to approach the criminal courts, thus facilitating their access to justice. In this way, the interests of the parties can be weighed to allow the Court to make just findings. Finally, the court pierced the corporate veil in this matter by holding the executives of a mining company liable for their failure to gain the proper authorisations and rehabilitate the mined areas. The Court opened the door for future prosecutions of environmental crimes of this nature and consequently sent a strong message to mining companies relating to the accountability of their executives and their duty to rehabilitate the areas in which they had mined. This judgment and its effect on environmental litigation highlighted above have deepened understanding of the water security discourse, the threat mining poses to water security, and the important role courts can play in executing justice for those parties affected.

\section{Conclusion}

Considering the findings above and considering the question posed at the beginning of this research, it is firstly proposed that courts execute the key roles identified in part four of this article. In discharging their duties, the use of supervisory interdicts should be affected where there is a possibility of non-compliance with the law. This would assist local authorities in discharging their socio-economic duties and restore confidence in the citizens affected. The Court would in this instance, play the role of guardian. However, the supervisory interdict unearths two possible obstacles. Firstly, if used haphazardly it may lose its force and, secondly, the resources required to monitor supervisory interdicts need to be funded or supplied. These questions regarding resources ultimately become an executive decision, which is far beyond the reach of the court.

Furthermore, when courts execute the roles identified in part five above, sustainability should be the most factor in guiding their decision-making. Sustainability ensures that access to water is not a temporary luxury but a 
right that can be enjoyed by generations to come. It also ensures that the environment is aptly catered for as well as socio-economic factors. The effects of climate change must also be considered, and the effect that water insecurity has on other human rights. When sustainability is the core aspect of policies regarding water security and access to water, the effects of those policies will not find temporary implementation and application. Courts must therefore make judgments that promote sustainability in the water security context.

Finally, the legislative framework for water security contains provisions that criminalise certain actions. These provisions should be used and where necessary applied to ensure that violators are appropriately sentenced, specifically in matters involving the pollution of water resources by mining companies that fail to prevent such pollution and to rehabilitate the areas in which they mine. The issue of criminal sanctioning applies only to harm already done. The notion that harm can be pre-empted to minimise the risk of such harm occurring is a measure that should not be overlooked. ${ }^{173}$

This article merely scratches the surface of the issues which are connected to water security. It has focused solely on a basic account of the theoretical perspectives of water security and briefly discussed the role that the court can play, considering the factors contained in the definition of water security. The author is aware of the related issues such as the complex history of the South African water law regime, which would include an intricate analysis of the effects of Apartheid spatial planning as a contributing factor, as well as interpretation issues including the separation of powers doctrine. This article seeks to highlight only the outcome of litigation in matters concerning water security, and how the court has dealt with and has ruled in such matters.

Water security is a topic that deserves much attention, particularly today when water is a scarce commodity. Water insecurity is detrimental to the country and has far-reaching effects on the poor and marginalised members of society. This problem is not confined to the borders of South Africa, as there is a global dilemma regarding the availability of freshwater. The difficulty in the South African context arises partly from the historical imbalances still present today. The complexity of the diverse interests involved in water and the limitations of the law and policies regulating these interests suggest that courts will continue to play an indispensable role in

173 World Commission on the Ethics of Scientific Knowledge and Technology Precautionary Principle 7. 
mediating these interests through the interpretation and enforcement of law and policy.

\section{Bibliography}

\section{Literature}

Brand 2011 Stell LR

Brand D "Judicial Deference and Democracy in Socio-Economic Rights Cases in South Africa" 2011 Stell LR614-638

Boisson de Chazournes, Leb and Tignino "Introduction"

Boisson de Chazournes LB, Leb $\mathrm{C}$ and Tignino $\mathrm{M}$ "Introduction" in Boisson de Chazournes LB, Leb $\mathrm{C}$ and Tignino $\mathrm{M}$ (eds) International Law and Freshwater: The Multiple Challenges (Edward Elgar Cheltenham 2013) 134

Budlender 2011 SAJHR

Budlender G "People's Power and the Courts: Bram Fischer Memorial Lecture, 2011" 2011 SAJHR 582-599

Cook and Bakker 2012 Global Environmental Change

Cook C and Bakker K "Water Security: Debating an Emerging Paradigm" 2012 Global Environmental Change 94-102

Cote and Van Garderen 2011 SAJHR

Cote D and Van Garderen $J$ "Challenges to Public Interest Litigation in South Africa: External and Internal Challenges to Determining the Public Interest: Current Developments / Case Notes" 2011 SAJHR 167-182

Du Plessis and Nel "Introduction"

Du Plessis A and Nel J G "An Introduction" in Du Plessis A (ed) Environmental Law and Local Government in South Africa (Juta Cape Town 2015) 3-39

Dugard 2010 Review of Radical Political Economics

Dugard J "Can Human Rights Transcend the Commercialization of Water in South Africa? Soweto's Legal Fight for an Equitable Water Policy" 2010 Review of Radical Political Economics 175-194 
Dugard and Maohlakoana 2009 SAJHR

Dugard $\mathrm{J}$ and Maohlakoana N "More Work for Women: A Rights-Based Analysis of Women's Access to Basic Services in South Africa" 2009 SAJHR 546-572

Fisher "Jurisprudential Model for Sustainable Water Resources Governance"

Fisher D "A Jurisprudential Model for Sustainable Water Resources Governance" in Kidd $\mathrm{M}$ et al (eds) Water and the Law (Edward Elgar Cheltenham 2014) 139-166

Fuo 2013 Murdoch U L Rev

Fuo ON "The Right of Access to Sufficient Water in South Africa: Comments on Federation for Sustainable Environment and Others $v$ Minister of Water Affairs [2012] ZAGPPHC 128" 2013 Murdoch U L Rev 21-37

Fuo 2017 De Jure

Fuo ON "Intrusion into the Autonomy of South African Local Government: Advancing the Minority Judgment in the Merafong City Case" 2017 De Jure 324-345

Gabru 2005 PELJ

Gabru N "Some Comments on Water Rights in South Africa" 2005 PELJ 1 34

Grey and Sadoff 2007 Water Policy

Grey D and Sadoff CW "Sink or Swim? Water Security for Growth and Development" 2007 Water Policy 545-571

Honkonen 2017 PELJ

Honkonen T "Water Security and Climate Change: The Need for Adaptive Governance" 2017 PELJ 1-26

Humby and Grandbois 2010 Les Cahiers de Droit

Humby T and Grandbois M "The Human Right to Water in South Africa and the Mazibuko Decisions" 2010 Les Cahiers de Droit 521-540

IPCC Climate Change 2014

Intergovernmental Panel on Climate Change Climate Change 2014: Synthesis Report - Contribution of Working Groups I, II and III to the Fifth Assessment Report of the Intergovernmental Panel on Climate Change (IPCC Geneva 2014) 1-151 
Kidd 2011 International Journal of Rural Law and Policy

Kidd M "Poisoning the Right to Water in South Africa: What Can the Law Do?" 2011 International Journal of Rural Law and Policy 1-17

Kotzé 2010 Journal of Human Rights and the Environment

Kotzé L "Phiri, the Plight of the Poor and the Perils of Climate Change: Time to Rethink Environmental and Socio-Economic Rights in South Africa?" 2010 Journal of Human Rights and the Environment 135-160

Kotzé and Du Plessis 2010 Journal of Court Innovation Kotzé LJ and Du Plessis A "Some Brief Observations on Fifteen Years of Environmental Rights Jurisprudence in South Africa" 2010 Journal of Court Innovation 157-176

Meissner et al "Establishment of Catchment Management Agencies" Meissner $\mathrm{R}$ et al "The Establishment of Catchment Management Agencies in South Africa with Reference to the Flussgebietsgemeinschaft Elbe: Some Practical Considerations" in Karar E (ed) Freshwater Governance for the $21^{\text {st }}$ Century (Springer Cham 2017) 15-27

Mirumachi Transboundary Water Security

Mirumachi N Transboundary Water Security: Reviewing the Importance of National Regulatory and Accountability Capacities in International Transboundary River Basins (Department of Geography, King's College London 2013)

Sadoff and Muller Water Management

Sadoff C and Muller M Water Management: Water Security and Climate Change Adaptation: Early Impacts and Essential Responses (Global Water Partnership Stockholm 2009)

Stein 2005 Tex $L$ Rev

Stein R "Water Law in a Democratic South Africa: A Country Case Study Examining the Introduction of a Public Rights System" 2005 Tex L Rev 2167-2183

Swart and Adams "Water Services Provision"

Swart $M$ and Adams NT "Water Services Provision and the Protection of Water Resources" in Du Plessis A (ed) Environmental Law and Local Government in South Africa (Juta Cape Town 2015) 445-480 
UN-Water Water Security

UN-Water Water Security and the Global Water Agenda: A UN-Water Analytical Brief (United Nations University Hamilton 2013)

Van Zyl 2008 PELJ

Van Zyl D "The Judiciary as a Bastion of the Legal Order in Challenging Times: FW De Klerk Lecture: 13 October 2008" 2008 PELJ 1-13

Versteeg 2006 Tilburg Foreign L Rev

Versteeg M "Equitable Utilization or the Right to Water? Legal Responses to Global Water Scarcity" 2006 Tilburg Foreign L Rev 368-392

Viljoen and Makama 2018 SAJHR

Viljoen S and Makama SP "Structural Relief: A Context-Sensitive Approach" 2018 SAJHR 209-230

World Commission on the Ethics of Scientific Knowledge and Technology Precautionary Principle

World Commission on the Ethics of Scientific Knowledge and Technology The Precautionary Principle (United Nations Educational, Scientific and Cultural Organization Paris 2005)

\section{Case law}

City of Johannesburg v Mazibuko (489/08) [2009] ZASCA 20 (25 March 2009)

Federation for Sustainable Environment $v$ Minister of Water Affairs (35672/12) [2012] ZAGPPHC 128 (10 July 2012)

Government of the Republic of South Africa v Grootboom 20011 SA 46 (CC)

Kenton on Sea Ratepayers Association v Ndlambe Local Municipality 2017 2 SA 86 (ECG)

Mazibuko v City of Johannesburg 2008 JOL 21829 (W)

Mazibuko v City of Johannesburg 20104 SA 1 (CC)

Minister of Health v Treatment Action Campaign 20025 SA 721 (CC)

National Treasury v Opposition to Urban Tolling Alliance 20126 SA 223 (C) 
NDPP v Blue Platinum Ventures 16 Pty Ltd and Matome Samuel Maponya: In re $S v$ Blue Platinum Ventures 16 (Pty) Ltd and Matome Samuel Maponya (Confiscation Order) (Naphuno Regional Magistrates' Court) (unreported) case number RN126/13 of 21 November 2014

$S v$ Blue Platinum Ventures 16 (Pty) Ltd and Matome Samuel Maponya (Sentencing Proceedings) (Naphuno Regional Magistrates' Court) (unreported) case number RN126/13 of 9 January 2014

\section{Legislation}

Bantu Homelands Citizens Act 26 of 1970

Constitution of the Republic of South Africa, 1996

Criminal Procedure Act 51 of 1977

Group Areas Act 41 of 1950

Local Government: Municipal Systems Act 32 of 2000

National Environmental Management Act 107 of 1998

National Water Act 36 of 1998

Natives Land Act 27 of 1913

Prevention of Organised Crime Act 121 of 1998

Water Services Act 108 of 1997

\section{Government publications}

GN R509 of GG 22355 of 8 June 2001

\section{International instruments}

UNCESCR General Comment No. 15: The Right to Water (Arts 11 and 12 of the International Covenant on Economic, Social and Cultural Rights) UN Doc E/C.12/2002/11 (2003)

\section{Internet sources}

Cremer Media Reporter 2014 http://m.miningweekly.com/article/miningcompany-director-receives-five-year-suspended-sentence-for- 
environmental-offences-a-landmark-victory-for-the-centre-forenvironmental-rights-2014-02-07/rep_id:3861

Cremer Media Reporter 2014 Mining Company Director Receives Five Year Suspended Sentence for Environmental Offences: A Landmark Victory for the Centre for Environmental Rights http://m.miningweekly.com/article/ mining-company-director-receives-five-year-suspended-sentence-forenvironmental-offences-a-landmark-victory-for-the-centre-forenvironmental-rights-2014-02-07/rep_id:3861 accessed 7 October 2018

Department of Water Affairs 2003 https://www.dwa.gov.za/Documents/ Policies/Strategic\%20Framework\%20approved.pdf

Department of Water Affairs 2003 Free Basic Water Implementation Strategy 2007 https://www.dwa.gov.za/Documents/Policies/Strategic\% 20Framework\%20approved.pdf accessed 9 March 2017

Department of Water Affairs 2013 https://www.dwa.gov.za/documents/ Other/Strategic\%20Plan/NWRS2-Final-email-version.pdf

Department of Water Affairs 2013 National Water Resource Strategy https://www.dwa.gov.za/documents/Other/Strategic\%20Plan/NWRS2-

Final-email-version.pdf accessed 9 March 2017

DPLG $2006 \quad$ https://www.westerncape.gov.za/text/2012/11/national_ framework_for_municipal_indigent_policies.pdf accessed 20 October 2017 Department of Provincial and Local Government 2006 National Framework for Municipal Indigent Policies https://www.westerncape.gov.za/text/ 2012/11/national_framework_for_municipal_indigent_policies.pdf accessed 20 October 2017

Global Water Partnership 2000 http://www.gwp.org/globalassets/global/ toolbox/references/towards-water-security.-a-framework-for-action.mobilising-political-will-to-act-gwp-2000.pdf

Global Water Partnership 2000 Towards Water Security: A Framework for Action http://www.gwp.org/globalassets/global/toolbox/references/towardswater-security.-a-framework-for-action.-mobilising-political-will-to-act-gwp2000.pdf accessed 23 October 2017

Lawyers for Human Rights 2012 http://www.lhr.org.za/news/2012/pressrelease-carolina-residents-oppose-municipalities-leave-appeal-application Lawyers for Human Rights 2012 Carolina Residents to Oppose Municipalities Leave to Appeal Application http://www.Ihr.org.za/ news/2012/press-release-carolina-residents-oppose-municipalities-leaveappeal-application accessed 20 October 2017 
Stats $\quad$ SA $2018 \quad$ http://www.statssa.gov.za/publications/

P0318/P03182019.pdf

Statistics South Africa 2019 General Household Survey 2018 http://www.statssa.gov.za/publications/P0318/P03182019.pdf accessed 5 August 2021

Truter 2014 https://www.werksmans.com/legal-briefs-view/environmentallaw-compliance-noose-tightening Truter J 2014 Environmental Law Compliance: The Noose is Tightening https://www.werksmans.com/legal-briefs-view/environmental-lawcompliance-noose-tightening/ accessed 7 October 2018

\section{List of Abbreviations}

CMA

DPLG

FBWIS

IPCC

Murdoch U L Rev

NEMA

NGO

NIP

NWA

NWRS

PELJ

SAJHR

Stats SA

Stell LR

Tex L Rev

Tilburg Foreign L Rev

WSA
Catchment Management Agency

Department of Provincial and Local Government

Free Basic Water Implementation Strategy Intergovernmental Panel on Climate Change Murdoch University Law Review

National Environmental Management Act 108 of 1998

Non-governmental Organisation

National Indigent Policy

National Water Act 36 of 1998

National Water Resource Strategy

Potchefstroom Electronic Law Journal

South African Journal of Human Rights

Statistics South Africa

Stellenbosch Law Review

Texas Law Review

Tilburg Foreign Law Review

Water Services Act 108 of 1997 